\section{Shoe-Leather Costs of Inflation and Policy Credibility}

\author{
Michael R. Pakko
}

Most people recognize that inflation is something to be avoided, but the popular public perception of inflation's harmful effects can be rather vague. In responses to survey questions about inflation, for example, most people express concerns about prices rising (defining inflation itself) or that it somehow erodes standards of living. ${ }^{1}$ When economists discuss the costs of inflation, however, they have more specific concerns in mind. One general class of inflationary consequences is sometimes referred to as the "shoe-leather" costs of inflation: In an effort to minimize the effect that inflation has on eroding the purchasing power of money, people have to spend more time and effort protecting the value of their nominal assets - wearing out their shoes on the way back and forth to the bank.

Of course, this quaint notion represents a much broader and more serious problem than simply the cost of wearing out ones shoes. To protect assets against inflation, societal resources are channeled away from productive activities and toward inflationhedging activities. In countries that have experienced hyperinflation, these resource misallocations are readily apparent; but they are also present for less extreme cases of inflation.

This article discusses the nature of shoe-leather costs in the context of a theoretical model economy. The shoe-leather costs themselves are represented by a "shopping-time" feature embedded in the model: It is assumed that individuals must spend time conducting transactions and that carrying money reduces the time required. The incentive to economize on money balances in the face of high inflation then implies that individuals incur a time-cost that rises in response to an increase in the inflation rate.

Using the U.S. experience of the postWorld War II (WWII) era to calibrate the model, I show that the shopping-time model implies shoe-leather costs that are broadly consistent with estimates derived by other researchers using a variety of approaches. In the previous literature, these costs have been presented as a comparison between two specific long-run inflation rates. In this article, I use the shopping-time model to take this analysis a step further, demonstrating how the transition from one inflation rate to another might be expected to proceed, and evaluating the importance of uncertainty about the commitment of the monetary authority to keep inflation in check. This analysis suggests that the credibility of the monetary authority is an important factor in evaluating the welfare gains that accrue from policies to reduce inflation.

\section{SHOE-LEATHER COSTS IN THEORY}

The nature of shoe-leather costs in a shopping-time approach to modeling money can be thought of as a generalequilibrium version of the inventory approach to money demand pioneered by Baumol (1952) and Tobin (1956). ${ }^{2}$ In the Baumol-Tobin model, individuals trade off the convenience of using money to conduct transactions against the opportunity cost of holding non-interest-bearing money; that cost being represented as the nominal interest rate. The cost of managing money balances is represented by a specific

\footnotetext{
1 Shiller (1996).

2 Karmi (1974), McCallum and Goodfriend (1987).
} 


\section{Figure 1}

Costs of Inflation as the Area Under the Money Demand Curve

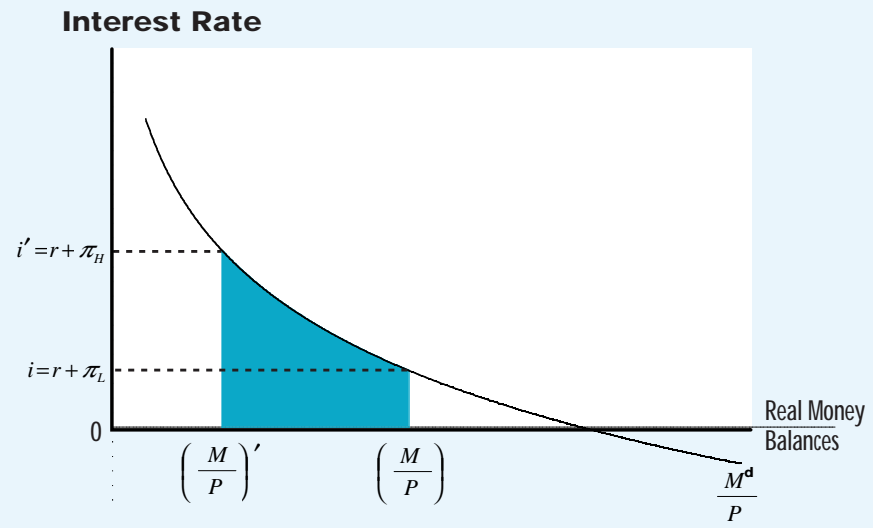

${ }^{3}$ Bresciani-Turroni (1937), Cagan (1956).

${ }^{4}$ One of Bresciani-Turroni's important points about the effects of the German hyperinflation was that wealthier members of society who had access to inflation hedges were at a huge advantage. This type of distributional distortion can be associated with costs, which are distinct from the shoe-eather costs that are the focus of this analysis. (Page 216.) brokerage fee which is charged for visiting a financial intermediary. Individuals balance the cost of making many trips to the "bank" against the cost of going infrequently and carrying around large money balances that earn no interest.

The outcome of this decision is an optimal number of trips to the bank and a corresponding level of money holdings, which depends (inversely) on the nominal interest rate. The shoe-leather costs of inflation emerge through the interest rates role in money demand. In particular, consider the standard Fisher equation, which represents the nominal interest rate as being comprised of two components: the real interest rate, and a term that compensates for expected inflation:

$$
\mathrm{i}_{\mathrm{t}}=\mathrm{r}_{\mathrm{t}}+\pi_{\mathrm{t}}^{\mathrm{e}} \text {. }
$$

When inflation and inflation expectations rise, so does the nominal interest rate. As a result, individuals economize on their money holdings, requiring more trips to the bank. The brokerage costs associated with these trips represent shoe-leather costs.

Although modeled as a specific fee, the brokerage cost in the Baumol-Tobin model can be interpreted more broadly as encompassing all of the various resource and time costs of managing ones financial assets and facilitating money payments. To gain some insight into the nature of these costs, it is informative to consider historical experience with extreme episodes of inflation, known as hyperinflation.

\section{AN EXTREME EXAMPLE}

The most famous episode of hyperinflation occurred in Germany in the 1920s. From mid-1922 through mid-1923, prices increased by a factor of 100 . By N ovember 1923 the price level was over one billion times its level in August 1922. ${ }^{3}$

Anecdotes of the distortionary effects of this hyperinflation abound. Workers were paid two to three times per day, rushing out to spend their pay before the money became worthless. At the pub after work, patrons ordered two beers at once in fear of the price rising before they had finished the first one. Shopkeepers posted prices as multiples of a base, changing the multiplication factor hourly after consulting with banks, which had set up phone lines to give the latest exchange rate quotes.

Indeed, the banking system expanded and took on crucial importance- especially for those with the resources to beat the devastating effects of inflation by holding foreign currency and precious metals. Bresciani-Turroni (1937) documented that the number of persons employed by German banks rose from about 100,000 in 1913 to 375,000 in 1923 . His description of this phenomenon provides a summary of the wastefulness of the financial sectors role during hyperinflation: "The increase in banking business was not the consequence of a more intense economic activity ... . The banks did not help in the production of new wealth; but the same claims to wealth continually passed from hand to hand."4

Of course, the effects of hyperinflation must be recognized as extreme examples of the destructive effect of inflation. It is not unreasonable to suppose, however, that costly distortions emerge on a smaller scale during more moderate periods of inflation. While the costs of hyperinflation 


\section{Some Estimates of the Costs of In ation}

\begin{tabular}{|c|c|c|c|}
\hline Study & Features & $\begin{array}{l}\text { Inflation } \\
\text { Comparisons }\end{array}$ & $\begin{array}{l}\text { Welfare Costs } \\
\text { (percent of GDP) }\end{array}$ \\
\hline Fischer (1981) & Welfare triangle & $10 \%$ vs. $0 \%$ & 0.3 \\
\hline Lucas (1981) & Welfare triangle & $10 \%$ vs. $0 \%$ & 0.45 \\
\hline Cooley/ Hansen (1989) & $\begin{array}{l}\text { RBC model with cash in advance } \\
\text { motive for money demand }\end{array}$ & $10 \%$ vs. optimal* & 0.387 \\
\hline Imrohoroglu (1992) & $\begin{array}{l}\text { Precautionary, consumption-smoothing } \\
\text { motive for money demand }\end{array}$ & $\begin{array}{l}10 \% \text { vs. } 0 \\
5 \% \text { vs. } 0\end{array}$ & $\begin{array}{l}1.07 \\
0.57\end{array}$ \\
\hline Dotsey/ Ireland (1996) & $\begin{array}{l}\text { Endogenous growth with cash in } \\
\text { advance and financial intermediation }\end{array}$ & $\begin{array}{l}10 \% \text { vs. } 0 \% \\
4 \% \text { vs. } 0 \%\end{array}$ & $\begin{array}{l}1.73 \\
1.08\end{array}$ \\
\hline Lucas (1994) & $\begin{array}{l}\text { Welfare triangle- with general } \\
\text { equilibrium motivation }\end{array}$ & $10 \%$ vs. optimal* & 1.3 \\
\hline
\end{tabular}

*Comparisons with the optimal refer to the Friedman rule of a slight deflation such that nominal interest rate is zero.

are enormous and obvious, the smaller costs associated with more mild inflation are more subtle and more difficult to measure empirically. ${ }^{5}$ An alternative approach is to calibrate a theoretical model economy and derive estimates from the models implications. We now turn to an examination of some estimates of inflations costs that are measured this way.

\section{MEASURING SHOE-LEATHER COSTS}

One approach to measuring the costs of inflation in less extreme circumstances exploits the role of the nominal interest rate in the money demand equation. As described in the context of the BaumolTobin model, an increase in expected inflation leads people to economize on their money balances and other nominal assets. It is the cost of minimizing money holdings which gives rise to shoe-leather costs. Hence, one way to measure the costs is to estimate the effects of a given rise in inflation on the demand for money. Because inflation can be thought of as a tax on money, demand analysis used to measure the welfare costs of taxation can be used to evaluate the costs of inflation. ${ }^{6}$
Figure 1 shows the effects of a change from a low inflation rate, $\pi_{L}$, to a higher inflation rate, $\pi_{\mathrm{H}} \cdot{ }^{7}$ As Equation 1 shows, this is associated with an increase in the nominal interest rate. The inverse relationship between nominal interest rates and the demand for money implies that individuals will respond by holding less money. The shaded area under the demand curve represents the resourcecost incurred when individuals economize on money-holding after the rise in the nominal interest rate, and represents the shoeleather costs of inflation. ${ }^{8}$

Note that the only nominal interest rate at which there are no costs of holding money is the point where the money demand curve crosses the horizontal axis- the satiation point for money balances, which is reached when the nominal interest rate is zero. From Equation 1, a zero nominal interest rate requires that expected inflation be negative. This property, known as Friedman's rule, is a property of many theoretical models of money demand, and is true of the shopping-time model of money demand to be introduced in the next section. ${ }^{9}$ The proposition that there are gains to be had by taking inflation to very low or even negative levels is controversial, and we have relatively little evidence on
${ }^{5}$ For example, the effects of inflation measured in crosscountry comparisons by Barro (1996) and Bruno and Easterly (1996) are largely attributable to the inclusion of high-inflation economies in their samples.

6 Baily (1956).

7 Carlstrom and Gavin (1993) illustrate this derivation using a Baumol-Tobin model of shoeleather costs.

8 The rectangle to the left of the triangle is the increase in tax revenue gained by the government or monetary authority. The governments revenue gained from inflationary finance is known as seigniorage.

9 Friedman (1969). 


\section{Figure 2}

\section{The Shopping-Time Function}

\section{Shopping Time}

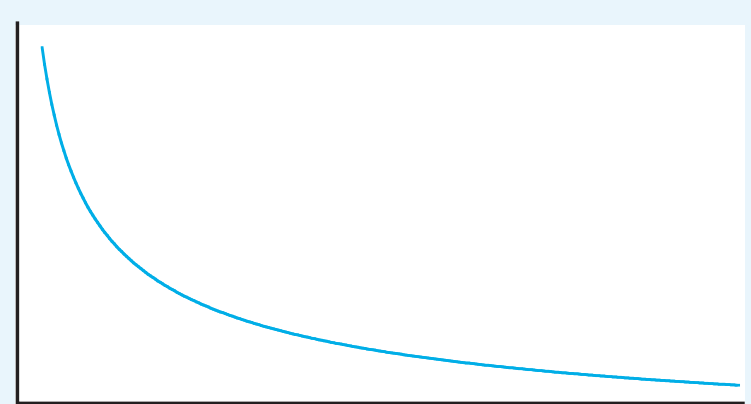

Real Money Balances

10 Mulligan and Sala-i-Martin (1997) show that small modifications of the theoretical satiation point can alter the optimal inflation rate and the relative costs of low inflation.

${ }^{11}$ Studies that have attempted to estimate the distortionary effects of interactions between inflation with the tax code, such as Altig and Carlstrom (1991), Feldstein (1996) and Bullard and Russel (1997), have found much higher costs. In this paper, I limit my analysis to shoe-leather costs.

12 The model is fully specified in the Appendix and in Pakko (1998). demand at such rates. ${ }^{10}$ Hence, it is not ative to zero.

Some of the estimates found in previous studies of the welfare cost of under-the-demand-curve approach to Lucas (1981) argued that the number While these might seem like small numbers, at today's level of output and $\$ 25$ billion and $\$ 40$ billion. rate on individuals in the model. For the demand for money motivated by a money demand specification, and found that the costs of inflation are higher. Imrohoroglu (1992) examined a model where the demand for money includes a precautionary, income-smoothing motive for money. Dotsey and Ireland (1996) consider an endogenous growth with cashin-advance money demand and financial intermediation. Lucas (1994) discussed the welfare costs of inflation in the context of a shopping-time model of money demand similar to the one examined in this article. These studies estimated the costs of 10 percent inflation to be as high as 1 to 2 percent of GDP. ${ }^{11}$

\section{A SHOPPING-TIME MODEL}

To demonstrate the way that shoe-leather which to base empirical estimates of money unusual for inflation costs to be measured relinflation are listed in Table 1. The first two lines in the table represent the areaestimating the costs of inflation. Fisher (1981) suggested that the cost of going from zero to 10 percent inflation amounted to the equival ent of three-tenths of 1 percent of Gross Domestic Product (GDP). might be closer to one-half of a percent. prices, they represent somewhere between

Another approach to estimating the costs of inflation is to specify a theoretical model of the economy, and then to calculate the effects of changes in the inflation example, Cooley and Hansen (1989) specified a basic real business cycle model with cash-in-advance constraint. They found that the costs of inflation were along the same order of magnitude as suggested in previous studies. Other researchers have introduced additional features of the costs can be cal culated using a model-based approach, I examine a general-equilibrium model where the costs of managing money balances are represented by a shopping-time function. ${ }^{12}$ In principle, the costs of inflation could be specified literally as a resource cost ( shoe-leather), or as a time cost. In the model examined here, I choose the latter approach, exploiting the relationship between inflation and increased time spent carrying out financial activities.

Specifically, individuals are assumed to have a motivation to economize on money balances in the face of rising inflation, and they weigh this incentive against the increased time cost of managing money or shopping. We assume that these time costs, $S_{t}$, are increasing in the level of consumption purchases, $C_{t}$, and decreasing in the quantity of real money balances (purchasing power) held by individuals, $M_{t} / P_{t}$; specifically:

$$
\mathrm{S}_{\mathrm{t}}=\mu_{1}\left(\frac{\mathrm{C}_{\mathrm{t}}}{\mathrm{M}_{\mathrm{t}} / \mathrm{P}_{\mathrm{t}}}\right)^{\mu_{2}},
$$

with $\mu_{1}>0$ and $\mu_{2}>0$. The parameter $\mu_{1}$ determines the average amount of time spent shopping, while $\mu_{2}$ measures the curvature of the shopping-time function. Figure 2 illustrates the nature of the relationship between real money balances and shopping time: For a given amount of 
expenditure, individuals can reduce the time spent shopping by holding more money. The time remaining to individuals after subtracting shopping-time is spent working, $\mathrm{N}_{\mathrm{t}}$, or enjoying leisure, $\mathrm{L}_{\mathrm{t}}$ :

$$
1-\mathrm{S}_{\mathrm{t}}=\mathrm{N}_{\mathrm{t}}+\mathrm{L}_{\mathrm{t}} .
$$

Firms hire labor and rent capital, $\mathrm{K}_{\mathrm{t}}$, from the households. They use the available technology for producing goods and services, $Y_{t}$, which they sell to the households,

$$
Y_{t}=\left(X_{t} N_{t}\right)^{1-\alpha} K_{t}^{\alpha}
$$

In Equation 4, $X_{t}$ represents an index of labor productivity that increases over time, determining the rate of long-run economic growth.

Output is allocated to consumption and investment, $l_{t}$, the latter providing for changes in the capital stock as:

$$
\mathrm{K}_{\mathrm{t}+1}=(1-\delta) \mathrm{K}_{\mathrm{t}}+\mathrm{I}_{\mathrm{t}}
$$

A central bank provides the money used in transactions, increasing the money balances of individuals each period by an amount $T_{t}$, so that total real money balances evolve over time by:

$$
\frac{M_{t+1}}{P_{t}}=\frac{M_{t}}{P_{t}}+\frac{T_{t}}{P_{t}}
$$

Individuals in the model are assumed to value consumption and leisure now and in the future. Their optimization problem can be used to find efficient allocations, which we consider to represent the outcome of an undistorted market economy - the equilibrium of the model.

By adjusting the values of money and prices by the average growth rate of money implied by $\mathrm{T}$ - and adjusting the levels of production, consumption and investment by the growth rate of technological progress implied by $\mathrm{X}$ - trends in the

\section{Figure 3}

Inflation and FIRE Employment as a Percentage of Aggregate Weekly Hours

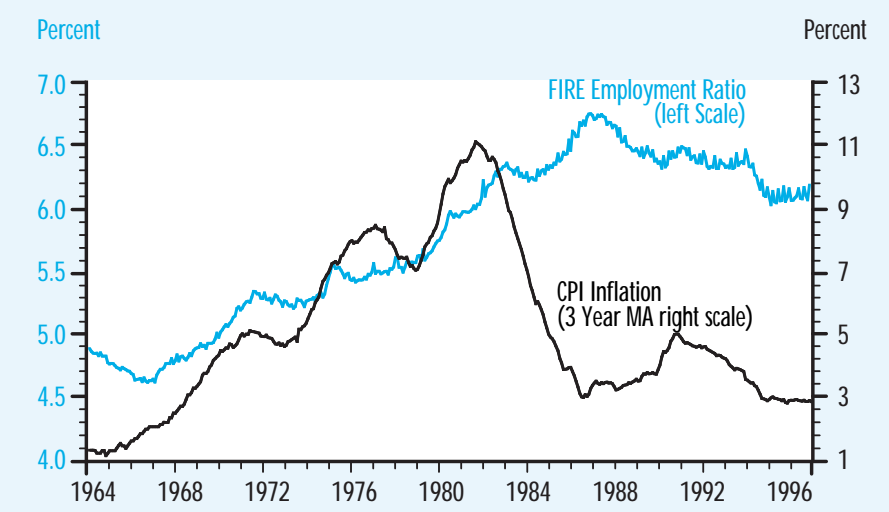

Source: Bureau of Labor Statistics

model are removed. Equilibrium then can be expressed in terms of relative levels of economic activity that depend on trend growth rates-including the inflation rate. ${ }^{13}$

These equilibrium solutions depend on some of the parameters of the model economy such as the relative returns to capital and labor, the long-run interest rate, long-run growth rates, and individuals attitudes about consumption and saving. The parameters used in this study are based on U.S. economic data during the post-WWII period and are selected to be consistent with previous specifications of similar models. ${ }^{14}$

One of the key relationships that emerges from the detrended solutions (represented now in lower case) is a money demand relationship,

$$
\frac{m_{t+1}}{p_{t+1}}=\left(\frac{\mu_{1} \mu_{2} w_{t+1} c_{t+1}^{\mu_{2}}}{i_{t}}\right)^{\frac{1}{1+\mu_{2}}}
$$

where $w$ represents the wage rate. ${ }^{15}$ Note that the relationship between real money balances and the interest rate, consumption, and wages crucially depends on the parameters of the shopping-time function, $\mu_{1}$ and $\mu_{2}$. For the purposes of subsequent analysis, values of these two parameters are selected by considering the growth of the financial sector during the
${ }^{13}$ Technically, the model is transformed to a stationary equilibrium, in which levels of economic variables depend on the average values of the growth parameters. See the Appendix for details.

${ }^{14}$ Specific values of the key model parameters are listed in the table accompanying the Appendix.

${ }^{15}$ As Lucas (1994) points out, relationships derived from a general-equilibrium model, such as this one, are not true demand equations in the sense that the right-hand variables determine the quantity of money demanded directly. Rather, Equation 7 summarizes a relationship that characterizes the jointly determined equilibrium values of money, prices, consumption and interest rates. 


\section{Table 2}

Effects and Welfare Costs of In ation in the Steady-State

\begin{tabular}{|c|c|c|c|c|}
\hline \multirow[b]{2}{*}{$\begin{array}{c}\text { Inflation } \\
\text { Rate (percent) }\end{array}$} & \multicolumn{4}{|c|}{ Relative to Zero Inflation (percent) } \\
\hline & $\begin{array}{l}\text { Percen } \\
\text { Consumption }\end{array}$ & $\begin{array}{l}\text { in*: } \\
\text { Leisure }\end{array}$ & $\begin{array}{l}\text { Welfare Co } \\
\text { Consumption }\end{array}$ & $\begin{array}{l}\text { nt of: } \\
\text { Output }\end{array}$ \\
\hline$-r * *$ & 1.90 & 0.06 & -2.05 & -1.59 \\
\hline 1 & -0.22 & -0.01 & 0.24 & 0.19 \\
\hline 3 & -0.61 & -0.02 & 0.65 & 0.50 \\
\hline 5 & -0.93 & -0.03 & 0.99 & 0.77 \\
\hline 10 & -1.61 & -0.05 & 1.70 & 1.32 \\
\hline
\end{tabular}

period of rising U.S. inflation during the 1960s and 1970s.

As discussed in the context of German hyperinflation, rising rates of inflation are associated with an increasing role for the financial sector as individuals seek to protect the value of their nominal assets from inflation. This relationship also has been observed in more recent high-inflation environments. For example, Lamb (1993) reported that the financial sector in highinflation Brazil during the early 1990s accounted for 15 percent of GDP-much higher than in most countries. Yoshino (1993) found a similar positive relationship between the size of the financial sectors and inflation rates for several countries.

In the U.S., the increase in inflation from the 1960s to the early 1980s was also associated with an increase in the relative size of the financial sector. For example, the fraction of the labor force employed in the finance, insurance, and real estate (FIRE) sector-plotted in Figure 3-rose from about 4.6 percent in 1965 to just over 6.7 percent during the mid-1980s. The growth of this measure slowed and turned downward following the disinflation of the 1980s.

The average value of the FIRE employment share over the sample period was approximately 6 percent. Obviously, not all activity in the FIRE sector is associated with shoe-leather costs of inflation, but neither are all shoe-leather costs associated with activity in that sector (or in the market, in general). Technological advances and deregulation are often cited as being particular factors related to financial sector growth throughout this period. Even so, technological innovation and regulatory initiatives were, to an extent, undertaken in reaction to the distortions emerging in an increasingly inflationary environment.

In an attempt to not overstate the share of shopping time represented by this admittedly crude measure, we cut the estimate in half: The scale parameter of the shoppingtime function, $\mu_{1}$, is set to yield a value of 3 percent of total work effort on average (at the 5 percent average inflation rate that prevailed during the sample period).

The efficiency conditions derived from the optimization problem of the model imply that shopping time is related inversely to the inflation rate. This can be used to pin down the curvature parameter (i.e., the elasticity) of the shopping-time function, $\mu_{2}$. The model predicts that the FIRE employment ratio will vary over its observed range in response to movements of trend inflation during the sample period (i.e., inflation rates of between about 2 and 10 percent) if the curvature parameter has a value near one. The parameterization $\mu=1.0$ is also consistent with empirical evi- 
dence that the interest elasticity of money demand is about one-half (as represented in Equation 7).

\section{SHOE-LEATHER COSTS IN THE SHOPPING-TIME MODEL}

With the calibrated version of the model in hand, we can calculate the welfare costs of changes in the trend rate of inflation. Specifically, the system of equations that define the models equilibrium can be solved for cases in which macroeconomic variables have settled at their long-run values, e.g., $y_{t}=y_{t-1}=y_{t-2}$, etc. This type of path is known as a steady state. Any particular long-run growth rate of money and prices will be associated with a specific steady state.

Table 2 provides a comparison of steady states for various inflation rates, showing the welfare costs of inflation at selected inflation rates. These costs are measured as the percentage of steady-state consumption (or output) that individuals would have to forego at zero inflation to make them indifferent about moving to a higher inflation rate. ${ }^{16}$ The estimates shown in Table 2 are broadly consistent with previous studies.

Table 2 also demonstrates the sources of these costs. As increases in the inflation rate induce people to economize on money balances, they increase their shopping time and decrease their consumption purchases. Leisure and work effort both decline to accommodate more shopping time, so production also falls. The economy contracts, including a decrease in the stock of productive capital.

The responses to changes in the inflation rate shown in Table 2 represent changes in the levels of economic activity. However, the effects of inflation often are considered in terms of sacrifices in economic growth. Although long-run economic growth in the model is independent of inflation, depending ultimately only on the rate of technological advance, the transition adjustments of the economy following a change in the inflation rate can give rise to adjustments

\section{Figure 4}

\section{Transition Path of Output Following an Increase in Inflation From 5\% to $10 \%$}

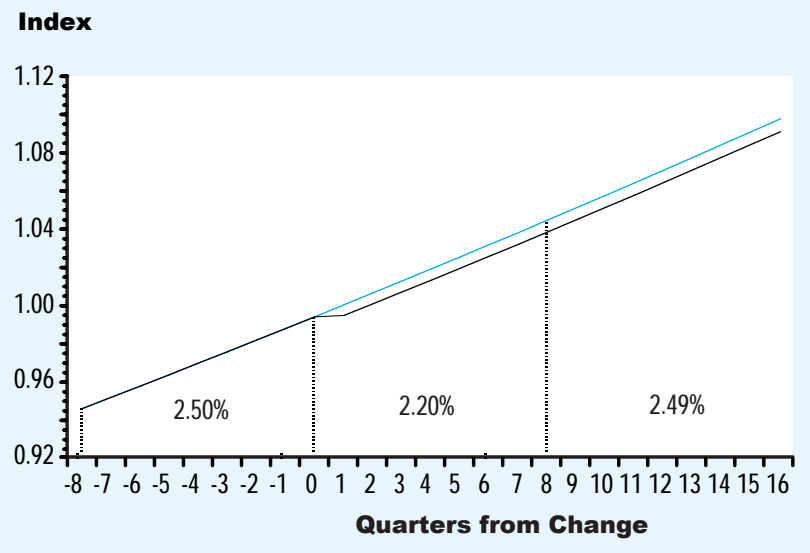

over time, which can temporarily change measured growth. ${ }^{17}$ This happens because the capital stock cannot be adjusted immediately; an increase in inflation results in lower investment, which (as shown in Equation 5) lowers the level of the capital stock over time.

\section{DYNAMIC ADJUSTMENT TO CHANGES IN THE INFLA- TION TREND}

Figure 4 shows the simulated transition path of the model economy following an increase in the rate of money growth and inflation from 5 percent to 10 percent. 18 Prior to the change, output grows at its long-run productivity-driven rate (set here to equal 2.5 percent), as it also will be after the economy has adjusted fully to the change in the inflation rate. During the period of transition, however, measured growth declines as the economy contracts over time. In Figure 4, during the two years following the increase in inflation, the average growth rate of the economy falls to 2.2 percent. During the first year after the change, growth is only 1.9 percent. After the brief period of adjustment, growth returns to near its long-run rate.

This analysis suggests that at least a portion (albeit small) of the measured growth decline observed during the inflationary 1970s might reflect this type of

\footnotetext{
${ }^{16}$ Specifically, the required compensation in terms of steadystate zero-inflation consumption, $\kappa$, is defined by the relationship:

$U\left[(1-\kappa) C_{0}, L_{0}\right]$ $=U(C, L)$

where the subscript 0 refers to steady state values at zero inflation.

${ }^{17}$ The notion that inflation affects the level of economic activitybut not the growth rate- is supported by empirical evidence cited in Bruno and Easterly (1996), who find that countries experiencing a temporary bout of high inflation (over 40 percent) tend to return to their original growth trends after the inflation crisis is removed.

${ }^{18}$ The models dynamic solutions are found using a log-linear approximation (around the initial steady state). The solution technique for the approximated system follows the approach described by King, Plosser and Rebelo (1988).
} 


\section{Figure 5}

\section{Inflation and the Michigan Survey of Inflation Expectations (Mean)}

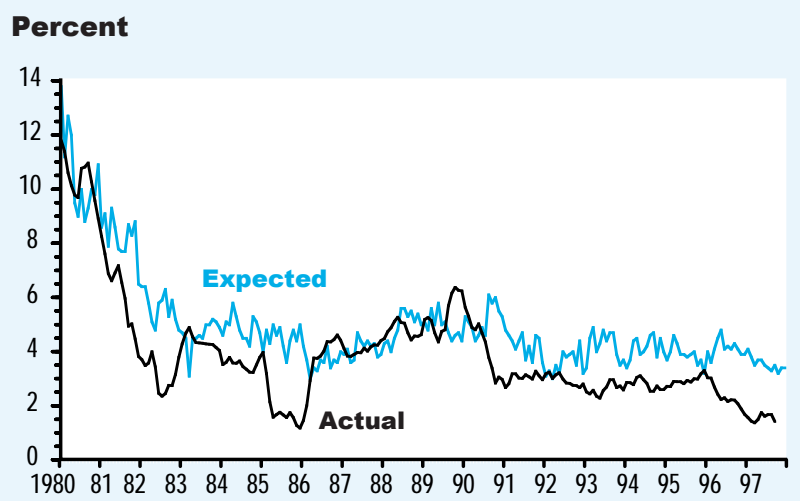

Source: Bureau of Labor Statistics and University of Michigan Survey Research Center, Mean expected price change.

${ }^{19}$ University of Michigan Survey Research Center.

20 This approach is an application of the Hamilton regime-shifting model (Hamilton, 1989,1994). This representation has been used to demonstrate the protracted adjustment of inflation expectations by Andolfatto and Gomme (1997) and Dueker and Fisher (1998).

${ }^{21}$ The latter source of innovations to the money supply is presumed to follow a first-order autoregressive process, with an autocorrelation coefficient of 0.72 (estimated from M2 growth, 1960 to1996). The standard deviation of the exogenous shock is set so that transitory shocks to the money supply growth rate account for about half of the overall variance of $\mathrm{M} 2$ growth over the sample period.

22 It is assumed that once the trend growth rate has fallen, it remains at the lower level with probability 1 (the low-growth trend is therefore known as an absorbing state). adjustment. Similarly, because the costs of higher inflation are symmetric to the benefits of lower inflation, at least a small share of increased economic growth experienced in the period following the early 1980s might be attributed to disinflation.

One problem with this explanation, however, is the rapid adjustment illustrated in Figure 4, in which over half of the change in output is complete after only one quarter. In response to the shift in the inflation trend, consumption and output immediately fall, and the remaining transition involves the adjustment of the capital stock to the new lower-equilibrium value. The fact that economic activity falls off so quickly is due largely to the assumption, made thus far, that the change in the trend rate of inflation is fully known to the public - and fully believed.

In fact, evidence suggests that sometimes the inflation expectations of the public are quite slow to adjust to actual changes in the inflation trend. Figure 5 shows one measure of these expectations, the mean estimate from an inflation survey conducted by the University of Michigan. ${ }^{19}$ Throughout the 1980s, this measure of expectations considerably lagged behind the decline in actual inflation.

This suggests an additional feature of the adjustment process that might be important: the formation of expectations about the inflation trend. In this regard, the credibility of the monetary policymaking authority al so becomes a factor. In the simulation shown in Figure 4, it is assumed that individuals are fully aware of the change in the inflation trend and respond accordingly. Suppose, however, that changes in the trend rate of inflation are not fully anticipated. In particular, let us assume that increases in the money stock sometimes reflect changes in the growth trend of money and inflation, and sometimes just reflect transitory movements of the money stock around the growth trend. When observing a particular change in the money supply, individuals attach a probability of less-than-100-percent to the likelihood that the inflation rate has actually changed, delaying adjustment until the weight of evidence supports a change in the trend rate of growth. People might attach a low probability to changes in the inflation rate when the implementation of such policies by the monetary authority are announced explicitly- if the policymaker has less-than-perfect credibility.

In the model, the formation of expectations can be represented by assuming that the trend of money growth can follow either a high-growth or a low-growth path. ${ }^{20}$ We also will assume that the money supply is subject to transitory fluctuations-complicating the process of deducing the true growth trend. ${ }^{21}$

Policy credibility is likely to be both particularly important and elusive when the monetary authority is attempting to implement a disinflationary policy following a surge of inflation. For the purposes of this illustration, therefore, we will consider the benefits derived from reducing the rate of inflation.

If the economy begins at the high money growth rate, the key parameter that determines expected inflation is the probability that the growth trend will change to the lower level. Equival ently, we can consider the probability that the inflation trend will not fall to the lower trend in any particular period, q. ${ }^{22}$ A relatively high value of $q$ implies a low probability that 


\section{Figure 6}

\section{Transition Paths Following a Permanent Reduction in the Inflation \\ Rate From 5\% to 3\%}
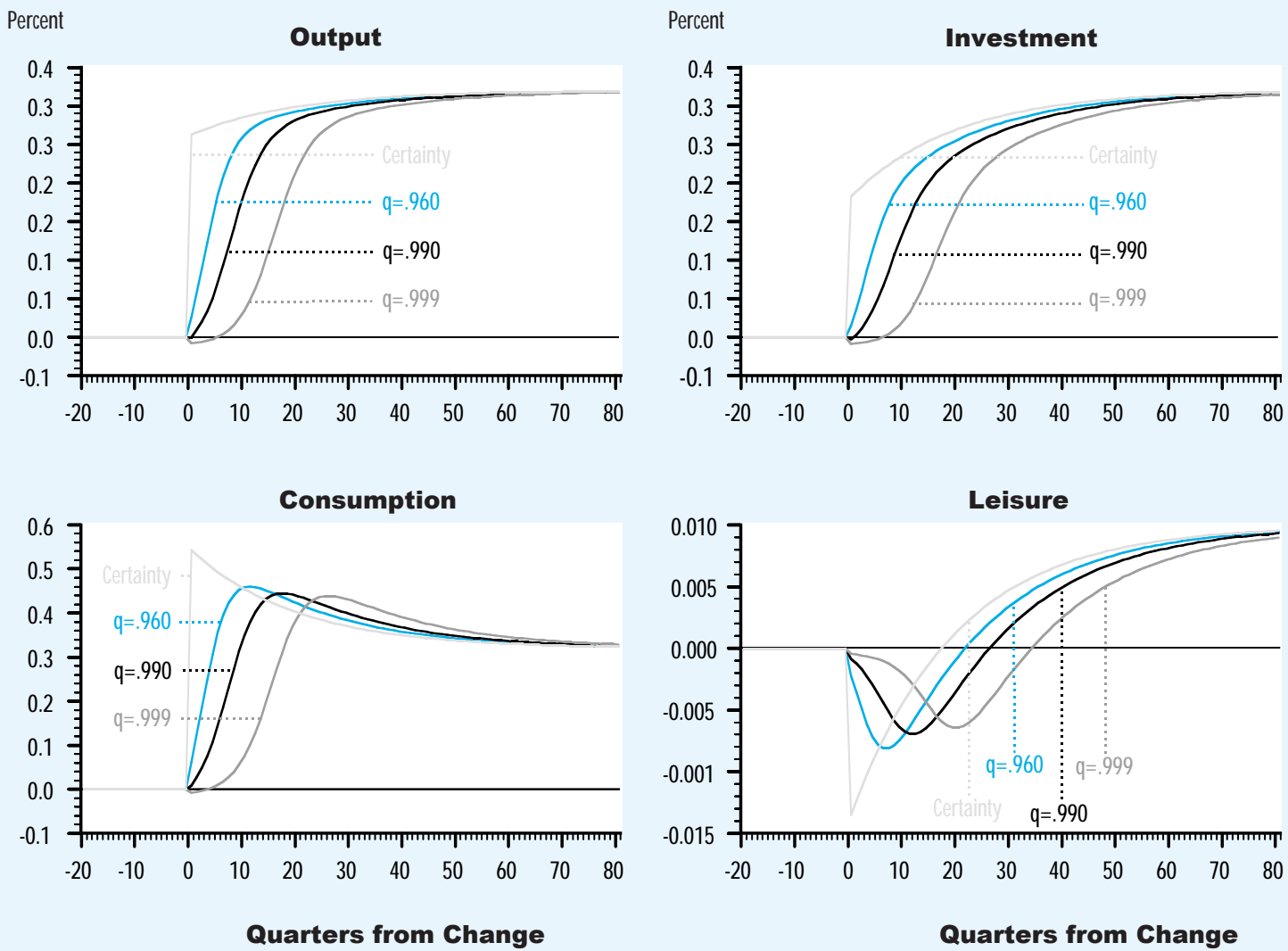

Quarters from Change

inflation will decline in any given time period, and can therefore be interpreted as reflecting, in part, the credibility of a monetary authority's disinflation policy. The unconditional probability of a change in the growth trend in any particular period should be considered quite low on averageafter all, shifts in inflation trends do not happen all the time- so the value of $q$ should be high. The shading of these probabilities to reflect policy credibility is then a matter of degree.

Figure 6 shows the paths of the economy following a decline in the inflation rate from 5 to 3 percent. The paths are calculated assuming that the probability of the inflation trend remaining high, q, takes on a higher (0.999), medium (0.99) or a lower (0.96) value. The higher value of $q$ is associated with the greatest degree of skepticism about the policymaker's intentions to lower the inflation rate. In order to illustrate clearly the effects of expectations on the adjustment process, the adjustment paths of economic quantities in Figure 6 are illustrated without trend growth. ${ }^{23}$

N otice that for each of the values of $q$, the adjustment process is more protracted than when the shift in the inflation trend is known with certainty. In the three cases with uncertainty, output reaches 90 percent of its ultimate increase only after 17,22 , and 30 quarters have passed. In the certainty case, only 11 quarters are required. ${ }^{24}$

For the upper value of $q$, notice that the lower inflation is initially associated with a decline in output and investment.

\footnotetext{
${ }^{23}$ The values used for inflation in the high and low regimes are adjusted for different values of $q$ to normalize steady-state values.

24 In the three cases where the shift in the inflation trend is unknown, individuals are 90 percent certain that they are in the low-inflation regime after 11,17 and 26 quarters.
} 


\section{Figure 7 \\ Cumulative Benefits of Lower Inflation As a Percent of Steady-State Welfare Gains}

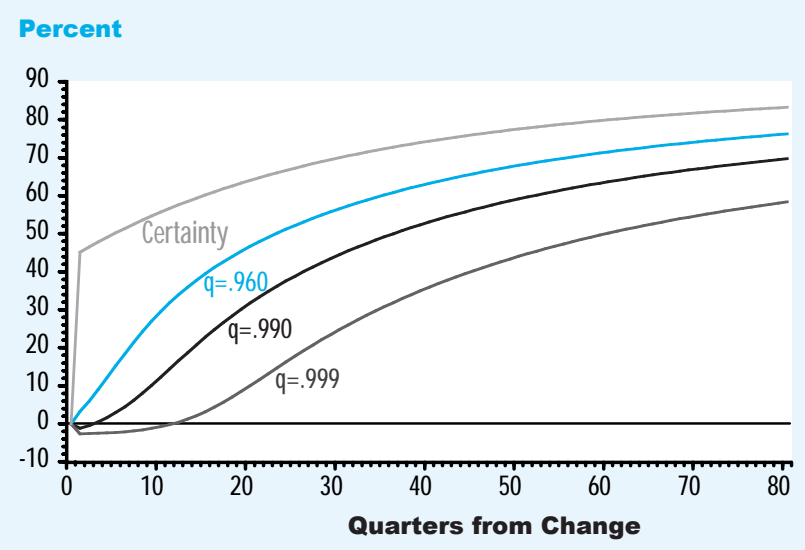

${ }^{25}$ We calculate these figures by comparing a discounted sum of the gains over the first n years with a similar discounted sum of the new steady-state values. The discount factor we use is the one assumed for the individuals in the model.

${ }^{26}$ Even in models where the short-un costs of disinflation are fairly high, the long-run benefits of lower inflation are ultimately considered to be larger. For examples of such calculations, see Carlstrom and Gavin (1993) and Neely and Waller (1997).
This happens because the shift in the money growth trend is initially mistaken for a transitory decline in the money supply, implying relatively higher money growth as money reverts back to its trend. It is only after observing the lower growth rate for several quarters that individuals are certain that the growth trend has changed and that economic variables begin the complete transition to the new steady state. Consequently, the temporary boost to economic growth is not as sharp, but it is more protracted.

The gradual adjustment to the new inflation trend also means that the welfare gains from a lower rate of inflation-as presented in Table 2- take time to be realized fully. Although individuals benefit from higher consumption and leisure as the economy adjusts, the cumulative gains from lower inflation will be considerably less than those associated with changes in the steady state- less, that is, than the benefits of lower inflation enjoyed by people who are born after the transition period is complete. Figure 7 shows the fraction of total cumulative benefits that are realized during periods subsequent to the actual change. ${ }^{25}$ Even after 10 years have passed, the cumulative benefits of lower inflation are 75 percent of the steady-state total for the case of complete certainty about the change in the inflation trend. When learning and credibility are issues, the cumulative gains after 10 years are only 64 percent, 54 percent and 37 percent of the total for the three values of $q$. For the lowest-credibility case, the initial decline in consumption and output takes time to offset, so cumulative welfare effects are negative for 11 quarters. It should be noted that although the cumulative benefits of lower inflation might be smaller and more drawn out over time, nevertheless, they are positive after only a few quarters. Moreover, it should be remembered that future generations benefit by the full magnitude of the welfare gains described in Table 2.

Many theoretical monetary models imply that short-run monetary contractions result in real economic contractions, even if they might eventually yield benefits of lower shoe-leather costs. The mechanism present in the shopping-time model, which is evident in the low-credibility case in Figure 6, is much weaker than in some other model frameworks. Many economists would argue that the shortrun costs of disinflation are larger than shown here. ${ }^{26}$ Nevertheless, this analysis has illustrated how the credibility of monetary policy-makers' commitment to lower inflation can mitigate those losses and accel erate the accrual of benefits from lower inflation.

\section{CONCLUSION}

Inflation can be harmful to an economy for many reasons. This article has discussed one of the most direct and pervasive of those costs, known as shoe-leather costs. Representing the time and effort devoted to protecting the value of one's purchasing power from the ravages of inflation, shoeleather costs are apparent in high-inflation economies. For more moderate inflation, the costs are more subtle and more difficult to measure, but still harmful nonetheless.

This article has demonstrated one approach to estimating the magnitude of shoe-leather costs using experiments from a general-equilibrium model of money 


\section{REVIEW}

NOVEMBER/ DECEMBER 1998

demand. When calibrated to the U.S. economy, the long-run costs of inflation implied by the model are consistent with a variety of previous estimates. These long-run costs - and the associated benefits of low inflation-are generally calculated without considering the transition effects from one inflation trend to another. This paper has demonstrated that these transitional effects can be important, delaying and limiting the ultimate welfare effects of inflation rate changes. An important feature of a successful policy of reducing inflation is credibility of the monetary authority-particularly when individuals in an economy have incomplete information about emerging inflation trends. When people are slow to understand or believe the permanence of lower inflation, the transition effects are larger and more protracted. Hence, policy credibility is not only important for achieving low inflation, it is also crucial for fully exploiting the potential benefits of low inflation.

\section{REFERENCES}

Andolfatto, David and Paul Gomme. "Monetary Policy Regimes and Beliefs," Institute for Empirical Economics of the Federal Reserve Bank of Minneapolis, Discussion Paper 118 (July 1997).

Baily, Martin J. "The Welfare Cost of Inflationary Finance," Joumal of Political Economy 64 (April 1956), pp. 93-110.

Barro, Robert J. "Inflation and Growth," this Review (May 1996), pp. 153-169.

Baumol, William J. "The Transactions Demand for Cash: An Inventory Theoretic Approach," Quarterly Joumal of Economics 66 (November 1952), pp. 545-556.

Bresciani-Turroni, Costantino. The Economics of Inflation: A Study of Currency Depreciation in Post-War Germany 1914-1923, Translated by Millicent E. Sayers, New York (1937).

Bruno, Michael and William Easterly. "Inflation and Growth: In Search of a Stable Relationship," this Review (May 1996), pp. 139-146.

Bullard, James and Steven Russell. "How Costly is Sustained Low Inflation for the U.S. Economy?" Working paper 97-012B, Federal Reserve Bank of St. Louis (1997).

Cagan, Phillip. "The Monetary Dynamics of Hyperinflation," in Milton Friedman (ed.) Studies in the Quantity Theory of Money, Chicago: University of Chicago Press (1956), pp. 25-117.
Carlstrom, Charles T. and William T. Gavin. "Zero Inflation: Transition Costs and Shoe Leather Benefits." Contemporary Policy Issues 11 (January 1993), pp. 9-17.

Cooley, Thomas F. and Gary D. Hansen. "The Inflation Tax in a Real Business Cycle Model," American Economic Review 79 (September 1989), pp. 733-748.

Inflations," Journal of Money, Credit and Banking 23 (August 1991,
Part 2), pp. 483-503.

Dotsey, Michael and Peter Ireland. "The Welfare Cost of Inflation in General Equilibrium," Journal of Monetary Economics 37 (February 1996), pp. 29-47.

Dueker, Michael and Andreas Fisher. "Switching Persistence Parameters in a Monetary Business Cycle Model," Manuscript, Federal Reserve Bank of St Louis (1998).

Feldstein, Martin. "The Costs and Benefits of Going from Low Inflation to Price Stability" National Bureau of Economic Research Working Paper 5469 (February 1996).

Fischer, Stanley. "Towards an Understanding of the Costs of Inflation II," Camegie-Rochester Conference on Public Policy 15 (Autumn 1981), pp. 5-42.

Friedman, Milton. The Optimal Quantity of Money and Other Essays, (Chicago: Aldine Publishing, 1969).

Hamilton, James D. "A New Approach to the Economic Analysis of Nonstationary Time Series and the Business Cycle," Econometrica 57 (March 1989), 357-384.

Hamilton, James D. Time Series Analysis, Princeton: Princeton University Press (1994).

Imrohoroglu, Ayse. "The Welfare Cost of Inflation Under Imperfect Insurance," Journal of Economic Dynamics and Control 16 (January 1992), pp. 79-91.

Karmi, Edi. "The Value of Time and the Demand for Money," Jourmal of Money, Credit, and Banking 6 (February 1974), pp. 45-64.

King, Robert G., Charles I. Plosser, and Sergio T. Rebelo. "Production Growth and Business Cycles: I. The Basic Neoclassical Model," Journal of Monetary Economics 21 (March/ May 1988), pp. 195-232.

Lamb, Christina. "A Rollercoaster Out of Control," Financial Times, February 22, 1993.

Lucas, Robert E., Jr. "Discussion of: Stanley Fischer, 'Towards an Understanding of the Costs of Inflation: II,'" Carnegie-Rochester Conference on Public Policy 15 (Autumn 1981), pp. 43-52.

\footnotetext{
. . "On the Welfare Cost of Inflation," Center for Economic Policy Research, Stanford University, Publication 394 (February 1994).
} 
McCallum, Bennett T., and Manin S. Goodfriend. "Demand for Money: Theoretical Studies," in The New Palgrave: A Dictionary of Economics, John Eatwell, Murray Milgate, and Peter Newman, eds. London: MacMillan; New York: Stockton Press (1987), pp. 775-781.

Mulligan, Casey B., and Xavier X. Sala---Martin. "The Optimum Quantity of Money: Theory and Evidence" Journal of Money, Credit, and Banking 29, (November 1997, Part 2), pp. 687-715.

Neely, Christopher J. and Christopher J. Waller. "A Benefit-Cost Analysis of Disinflation." Contemporary Economic Policy (January 1997), pp. 5064.

Pakko, Michael R. "Dynamic Shoe-Leather Costs in a Shopping-Time Model of Money," Working Paper 98-007A, Federal Reserve Bank of St. Louis (1998).

Shiller, Robert). "Why Do People Dislike Inflation?" National Bureau of Economic Research Working Paper 5539 (1996).

Tobin, James. "The Interest-Elasticity of Transactions Demand for Cash," Review of Economics and Statistics 38 (August 1956), pp. 241-247.

Yoshino, J.A. "Money and Banking Regulation: The Welfare Costs of Inflation," Ph.D. dissertation, Department of Economics, University of Chicago, Chicago, IL (1993). 


\section{THE SHOPPING-TIME MODEL}

\section{Preferences and Technology}

A single representative agent maximizes a discounted stream of utility derived from consumption, $\mathrm{C}$, and leisure, L:

$$
\max \sum_{\mathrm{t}=0}^{\infty} \beta^{\mathrm{t}} \mathrm{U}\left(\mathrm{C}_{\mathrm{t}}, \mathrm{L}_{\mathrm{t}}\right),
$$

where the utility function defines a composite good using a Cobb-Douglas function in $\mathrm{C}_{t}$ and $\mathrm{L}_{\mathrm{t}}$, and displays constant relative risk aversion with respect to the composite:

$$
U\left(C_{t}, L_{t}\right)=\frac{1}{1-\sigma}\left(C_{t}^{\theta} L_{t}^{1-\theta}\right)^{1-\sigma} .
$$

The time endowment and shoppingtime technology are described in the text. The agent faces a sequence of budget constraints given by:

$$
Y+\frac{M_{t}^{\prime}}{P_{t}}+\frac{T_{t}}{P_{t}}=C_{t}+I_{t}+\frac{M_{t+1}^{\prime}}{P_{t}},
$$

where investment, $l_{t}$, is gross capital accumulation as shown in Equation 5 in the text.

Output is produced using capital and labor via a constant returns-to-scale, Cobb-Douglas function:

$$
Y_{t}=F\left(K_{t}, X_{t} N_{t}\right)=K_{t}^{\alpha}\left(X_{t} N_{t}\right)^{1-\alpha},
$$

where $X_{t}$ represents labor augmenting technical progress, which is assumed to grow at a constant rate $\gamma$.

The money stock evolves over time with fluctuations, $\mathrm{v}_{\mathrm{t}}$, around a growth trend, $\mathrm{G}_{\mathrm{t}}$ :

$$
M_{t}=G_{t} e^{v_{t}},
$$

where $\mathrm{G}_{\mathrm{t}}=\mathrm{gG} \mathrm{t}_{\mathrm{t}-1}$ and, $\mathrm{v}_{\mathrm{t}}=\rho_{\mathrm{v}} \mathrm{v}_{\mathrm{t}-1}+\varepsilon_{\mathrm{t}}$ with $\varepsilon_{\mathrm{t}}$ a normally distributed random variable.

\section{Stationa ry Transformations}

In order to examine the model's dynamics, the problem is first transformed to a stationary representation. This involves adjusting the real variables for trend productivity growth $(\gamma)$ and the nominal variables for trend money growth rate $(\mathrm{g})$.

To adjust for productivity growth, divide all quantity variables by $X_{t}$. With this modification, the capital accumulation equation becomes:

$$
2 \mathrm{k}_{\mathrm{t}+1}=(1-\delta) \mathrm{k}_{\mathrm{t}}+\mathrm{i}_{\mathrm{t}},
$$

where lower case is used to represent the transformed stationary variables. A1 The growth rate of nominal variables is determined by the growth rate of $G_{t} g$. Dividing $M_{t}{ }_{t}^{\prime}$ and $P_{t}$ by beginning-of-period money balances $G_{t}$ (yielding transformed variables $m_{t}^{\prime}$ and $p_{t}$ ), the nominal side of the model is rendered stationary. This modifies the budget constraint to be:

$$
y_{t}+\frac{m_{t}^{\prime}}{p_{t}}+\frac{t_{t}}{p_{t}}=c_{t}+i+g_{t} \frac{m_{t+1}^{\prime}}{p_{t}} \text {. }
$$

The first-order condition for the agent's choice of money balances to carry forward, which can be expressed as:

$$
\left(1+\mathrm{i}_{\mathrm{t}}\right)=\mathrm{E}_{\mathrm{t}}\left\{1+\mathrm{w}_{\mathrm{t}+1} \mathrm{~S}_{\mathrm{M}}\left(\cdot_{\mathrm{t}+1}\right)\right\},
$$

reflects the trade-off of the opportunity cost of holding a dollar, the nominal interest rate, against the marginal benefit of lower future shopping time. Equation A7 can be rearranged to yield the money demand relationship in the text.

\section{Calibration}

Parameters of the dynamic system are calibrated by matching long-run characteristics of the U.S. economy to the models steady state solutions. Table A1 lists the
Al The transformation of consumption also alters the effective rate of time preference. See King, Plosser and Rebelo (1988). 


\section{REVIEW}

NOVEMBER/ DECEMBER 1998

\section{Table A1}

\section{Baseline Parameter Values}

\begin{tabular}{|l|c|c|c|}
\hline \multirow{2}{*}{ Preferences } & Description & Symbol & Value \\
\cline { 2 - 4 } & Discount factor & $\beta$ & 0.99 \\
\hline Technology & Intertemporal substitution & $\sigma$ & 2 \\
\hline Chopping Time & Consumption share & $\theta$ & 0.322 \\
\hline \multirow{3}{*}{ Growth Trends } & Capital's share & $\alpha$ & 0.3 \\
\hline & Capital depreciation rate & $\delta$ & 0.025 \\
\hline & Scale parameter & $\mu_{1}$ & 0.0111 \\
\hline
\end{tabular}

key model parameters. Most have been selected to be consistent with previous calibrations of equilibrium business cycle models. ${ }^{A 2}$ The steady state per-capita growth rate and the inflation rate are set at their long-run average values of 1.6 percent and 5 percent annually. Capital's share in production, $\alpha$, is set to 0.3 and the capital depreciation rate, $\delta$, is 10 percent per year. The discount factor is 0.99 , and the coefficient of relative risk aversion is set to equal 2. Leisure's share in overall utility, $(1-\theta)$, is selected to yield steadystate work effort as a fraction of the total time endowment at 0.3. Selection of the parameters of the shopping time function is discussed in the text. 